\title{
Financial and Fiscal Reporting, the Effect on the Financial Statements: The Case of Vlora
}

\author{
Brisejda Zenuni Ramaj \\ PhD Lecturer in Financial and Accounting Department, \\ University of Vlora “Ismail Qemali”, Faculty of Economy
}

\section{Abstract}

Understanding and analyzing accounting and fiscal reporting practices is by no means simple, as they are characterized by complexity and ongoing dynamics. The relationship between accounting and fiscal reporting and the correlation that exists between them is one of the most debated and analyzed phenomena worldwide. It is an early relationship that has evolved over time and has often been accompanied by discussions about its convergence and divergence. The fiscal system has also undergone numerous changes, which has given its impact on the reporting of economic entities. These changes are an integral part of the process of reforming the fiscal system, which has faced many challenges, which definitely require high efficiency and effectiveness, led by the aspiration to be as close as possible to European standards. Often these changes in the fiscal system have not provided scope or do not converge with the accounting rules, which have served as the beginning of the creation of dual models of accounting and fiscal reporting. In this paper, both primary and secondary data were used. Primary research was based on quantitative research through the distribution of questionnaires and qualitative research through interviews with financial experts of entities and tax administration officials. On the other hand, economic development and the intention to be part of European countries, has brought the need for global integration of the capital market. Global investors are interested in cross-border financial reporting, making it a necessity to implement International Accounting Standards and adapt them to the spaces created by our country. The information needs of global investors have forced accounting professionals and institutes to work for harmonization. The result of the work is the construction and testing of an important conceptual model that dictates the potential factors of creating differences in reporting, as a result of dual reporting models. Therefore, there has long been a need for companies around the world to communicate using a common accounting language. Country-specific principles are so diverse that the aspiration for an integrated 
global capital market can only be fulfilled through a uniform financial reporting code.

Keywords: Financial Reporting, Tax Reporting, National Accounting Standards, Harmonization

JEL classification: M40, M41, M48, K34, Discipline: Accounting

\section{Introduction}

The relationship between accounting and taxation is a relationship that has existed, exists and will continue to exist therefore more interest has been added to questions about the intensity, interrelationship and mutual consequences between them. Therefore, it is of a great importance that the information on the elements included in the financial statements is correct, coherent and based on legal regulations. When accounting is crossed with taxes, there are many topics that can be discussed. Variables such as income, expenses and profits are used by both financial accounting and taxes. They measure and report on the same transactions and circumstances. Sometimes they are calculated in the same way, but often there are circumstances in which different figures are appropriate for each of the systems. The basic point of course is that accounting and taxation exist for different reasons. Accounting involves the preparation of information for audit and decision-making purposes and may require interpretation as well as recording of factual information. Whereas, the main purpose of taxation is usually revenue collection. Taxation is also used as an instrument of government economic and social policy. For a tax system to function successfully within the law requires a degree of assurance that may not always be appropriate for financial and commercial accounting. Furthermore, there may be alternative methods of preparing accounts that are equally acceptable in terms of accounting standards, but the choice of which may be inappropriately affected by tax implications. In recent years, decisions in some cases seem to have shown a move towards an even greater reliance on accounting for tax purposes. Although commercial accounts prepared on the basis of financial reporting standards may often be the most appropriate basis for tax reporting and the preparation of tax returns, this is not always the case. For as long as there will be changes it seems that perfect harmonization between taxation and accounting will not be able to happen. The global move towards International Accounting Standards can also be seen as a reason to review the close relationship between accounting principles and tax practice and law, as well as a step towards harmonizing the tax base. There are different levels of dependency within countries and no country is able to avoid the difficult relationship between accounting and taxation. The evolving tax law influenced by many factors may deviate from the initial intentions of tax policymakers. It is therefore suggested that tax law should be constantly reviewed to ensure that it is meeting the needs of modern business practice and the principles and integrity of the tax system. 


\section{Purpose of the study}

The purpose of this study is to show the relationship between financial reporting and tax reporting, focusing on some elements of financial statements to show what is the right way to present them and how they are classified according to Lamb et al. which expresses the influence of laws on the manner of fair reporting. Their relationship is so close and essential to stakeholders that the topics of discussion are very diverse. This study touches on some elements that affect the creation of dual reporting models, consequently the differences in these reports and where they are most evident in the financial statements.

\section{Objectives}

- Establishment of a theoretical and practical basis on the possible differences between financial and fiscal reporting and the potential factors that influence their creation, and consequently the creation of dual reporting models.

- To study and analyze which are the main components where the differences are most evident in the accounting and fiscal estimates of entities, presented in the financial statements.

- Indicate the impact of the law on accounting and how it is classified according to Lamb et al.

\section{Research questions}

Based on the above, accounting and fiscal reporting (valuation) are considered as a very important element in the decision-making process. However, given the current gaps in the literature, more studies are needed. As such, this study addresses the following questions:

1. How are the economic units operating in the Region of Vlora oriented towards the application of accounting and fiscal rules in the assessment of their activity and financial situation?

2. Are there duplicate models and differences in financial and fiscal estimates in entities and what are the main factors influencing their creation?

3. Where are the differences in accounting and fiscal estimates most evident in the financial statements of entities?

\section{Financial reporting and tax system}

Despite the continuing tendency of entities to pay lower taxes, the tax system needs to play its role as a regulator and be in continuous progress in terms of harmonization with accounting standards. The relationship between accounting and taxation is evolving and more complex than it initially seems. According to Green S.(1995): "Financial accounting and tax accounting are not the same. They have different 
objectives, are subject to different rules and serve different purposes ${ }^{1}$. In addition to the existing difficulties, both accounting and taxation are in an ongoing development process. The different degree, method and direction in which each develops the resulting conflicts between the two systems continue. The relationship between accounting and fiscal is an early relationship that has evolved over time, which has often been accompanied by discussions and debates about its convergence and divergence. The internationalization of the economy leads to economic globalization which is interpreted by the totality of its components, but for us, a special interest is the globalization of accounting and taxes. Although there was a synthesis in the beginnings of creating the "relationship" between accounting and fiscal reporting, today the financiers and accountants of entities need to work harder in order to coordinate and coordinate objectives that often appear to be conflicting.

Currently, as a result of globalization, the development of economic relations between countries, witnesses of a process of cooperation are seen in tax institutions, as well as the increasing role and involvement of the Organization for Economic Cooperation and Development (OECD) and the European Union (EU) in direction of drafting common rules of conduct. Depending on the nature of the prevailing tax, they may differ as follows:

- Tax systems with a predominance of direct taxes, as specific to governments which are more favored from an economic perspective and which are based on global income tax and income tax of legal entities;

- Tax systems dominated by indirect taxes, as specific to underdeveloped countries or those subject to an economic crisis;

- Tax systems with a complex predominance, as specific to economically developed countries, with balanced systems: social - economic systems, social - democratic political regimes;

- Tax systems which are dominated by general taxes, as specific to more developed countries, tax authorities and accounting structures are well organized. These systems are dominated by income tax and value added tax (VAT)

- Tax systems where special taxes dominate, where taxes are set according to different income categories and vary in types.

Over the past two decades, our country has undergone major changes. Political, social and economic changes created the immediate need for an immediate review of budgetary and fiscal policies. Of course, our fiscal system has also become part of these changes, which has given its impact on the reporting of entities and the tax system, shortcomings that had to be overcome in order to expand the private sector and promote tax reform.

1 Green S. (1995) “Accounting standards and Tax Law: Complexity, Dynamism and Divergence”, page $445-451$ 


\section{Methodology}

In the realization of this work, both primary and secondary data were used. Primary research is based on quantitative research through the distribution of questionnaires and qualitative research through interviews with financial experts of entities and tax administration officials. Also, in the paper I used the qualitative method. On one hand, theoretical analysis has been carried out in the form of comparison and description between the two forms of reporting (qualitative research). This paper is also based on a qualitative method, the purpose of which is to identify the importance of studying financial and tax reporting in order to identify and avoid overlaps in the financial statements. The resources provided are primary and secondary. Literature and indepth interviews with financial experts and heads of entities have served as the basis for building the questionnaire, as a very important instrument in primary data collection. Secondary sources consist of scientific articles, texts of professors in the field, foreign literature, and reports from institutions. Which is the result of reviewing an extensive and contemporary academic literature, foreign and domestic, regarding accounting arrangements, accounting / financial standards, fiscal system and fiscal reporting, as well as the relationship between these two reports? From the analysis of this literature, the main dimensions of the orientation of the relationship between accounting and fiscal (consequently the relevant estimates) were identified. The literature was extensive and helped me a lot to focus on many different issues.



Figure 1: Designing the relationship between research questions and hypotheses

\section{Variables}

The variables considered in the paper are: The dependent variable in this paper is the differences in accounting and fiscal reporting (estimates).

The independent variables in this paper are: 
- Impact of accounting standards

- Frequency of changes in fiscal legislation

- Different accounting and fiscal purposes

- Integrity and professionalism of the tax administration

- Tax rate

- Complexity of fiscal rules

- The culture of taxpayers

- Trust in fiscal policy and implementing institutions

- Size of economic units (the basic classification criterion is that of turnover according to the fiscal classification, specifically in small business without VAT, small business with VAT, large business and VIP)

Bartlett's Test of Sphericity- which is based on the examination of the observed variance-covariance matrix. According to this test it is checked if this matrix is an identity matrix. A matrix identity is a matrix in which the elements on the diagonal are one and the elements outside the diagonal are zero. If they are going to be one, that means the group variances are the same, so there is no variation between the variables. In the same matrix the diagonal elements show the covariance. If they will be zero or very close to zero this means that the variables are not correlated. If the test turns out to be insignificant, then this means that the correlations between the variables are zero or close to zero, so the variables cannot form groups or factors. When it gets a value less than 0.05 it indicates that factor analysis can be useful for our data. Kaiser-Meyer-Olkin (KMO) - The KMO indicator varies between 0 and 1 .

Multiple Logistic Regression Analysis- In testing the third hypothesis, the questionnaire data were processed in order to test and explain the relationships that exist between the factors and the dependent variable difference in accounting and fiscal estimates. These relationships have been studied and tested using the statistical model of multiple logistic regressions. This type of regression has similarities to regression in the form of a linear equation. In the simplified form, when there is only one independent variable, the form of the logistic regression equation estimating the probability of $\mathrm{Y}$ is given:

$$
P(Y)=\frac{1}{1+e^{-\left(\beta_{0}+\beta_{1} X_{1}\right)}}
$$

$\mathrm{P}(\mathrm{Y})$ - is the probability that a certain attribute of $\mathrm{Y}$ occurred,

e- is the basis of natural logarithm

$\beta \mathrm{i}$-are coefficients from a linear combination similar to a simple linear regression.

Logistic regression can also be with many independent variables, which can write: 


$$
P(Y)=\frac{1}{1+e^{-\left(\beta_{0}+\beta_{1} X_{1}+\beta_{2} X_{2}+\ldots+\beta_{n} X_{n}\right)}}
$$

Model evaluation: measured between the Wald test

This statistic has a special distribution, known as Hi-square. Both the test in linear regression and the Wald statistic show whether the coefficient $b$ is significantly different from zero. It is mainly used to ascertain whether the variable is an important predictor of results (Field, 2009).

$$
\mathrm{Wald}=\frac{b}{\mathrm{SE}_{b}}
$$

The simplest way to estimate Wald is to look at the significance level and if it turns out to be less than 0.05 it is concluded that this variable has a significant contribution to the prediction of the independent variable (Field, 2009).

\section{Data analysis and findings}

The questionnaire was distributed to the accounting officers of economic entities operating in the Region of Vlora and only 95 of them returned answers. In the surveyed economic units (41\%) they exercise activity in wholesale or retail trade. At the same time, this is the largest sector of the surveyed units. The next largest group consists of those operating in manufacturing $(22 \%)$ and then ranks the service sector with about $14 \%$ of the surveyed units. On the other hand, the construction sector occupies about $11 \%$ of the units that completed the survey. Meanwhile, the transport and public services sector accounts for $8 \%$ of the volume of surveyed units. The rest consists of those operating in the finance and insurance sector (3\%) and agriculture, forestry and fisheries (1\%).

\section{Checking the first hypothesis}

From the survey conducted in the economic units it results that all the dimensions presented in the evaluation questionnaire receive a higher than half of the Lamb scale, implying that in general the economic units that exercise their economic activity in the Region of Vlora "tilt" or "tend" towards evaluation according to the category where fisk dominates.

The total rating for the various aspects of reporting on a scale from 1 to 5 reaches

Level 4,354 out of 5 in totals, which mean the dominance of fiscal regarding unit valuations and reporting. According to the survey results, entities are oriented towards the application of the rules of accounting and fiscal standards but dominated by fiscal ones in assessing their activity and financial condition. This means that the hypothesis raised is accepted. 


\section{Control of the second hypothesis}

To study the differences in the accounting / fiscal reporting of entities, respondents were asked to express their agreement (according to the Likert scale from 1 to 7 ) regarding the statement: "There are differences in accounting estimates and those fiscal during the exercise of the activity in the evaluation of the activity and the financial condition of your business"

The results from the questionnaire show that there are significant differences in the accounting and fiscal reporting during the exercise of the activity in the evaluation of the activity and the financial condition of the business since the collected answers reach the measure $\mathbf{6 . 0 8}$ out of $\mathbf{7}$ maximum. This serves as a dependent variable to check other hypotheses following the paper.

The following are statistics on differences in financial and fiscal estimates. There are 95 cases and their average rating is $\mathbf{6 . 0 8}$ on a scale of 1 to 7 . The standard deviation indicating for rating fluctuations is $\mathbf{0 . 7 5 4}$. It is confirmed that there are significant differences in accounting and fiscal reporting during the exercise of the activity in assessing the activity and financial condition of the entity. In this way the second hypothesis gets the answer: it is accepted.

\section{Control of the third hypothesis}

Data collected from the questionnaire and results from the analysis so far. First, the question related to differences in financial estimates (reporting) serves as a dependent variable. We transform this question in the service of further analysis. On the other hand, in the questionnaire the design and composition of questions to gather the information needed to present the factors (independent variables) and to answer the above hypotheses is done as focusing on several dimensions according to the treatment in the chapter of methodology.

First, we recode the dependent variable of differences in estimates according to the format of a dummy variable with values 0 and 1 , where the latter is taken for cases where the difference is estimated at the level above 4 and vice versa.

Second, we have the transformation of the model independent variables. To achieve this we use the dimension reduction procedure, which allows us to "compress" questions into a single variable.

The Model Summary table informs about the coefficient of determination of the variance of the dependent variable through independent factors. Since the dependent variable is dichotomous, ie dummy, then the R-square does not carry the same interpretive power as in the one-factor or multivariate linear regression, but nevertheless there are some R-squares, which are:

- Cox and Snell R2, which relies on the final model log-likelihood and the base model log-likelihood and data count. 
Specifically:

$$
R_{C S}^{2}=1-e^{\left(-\frac{2}{n} l_{l o g-l i k e l i h o o d} \text { final-log-likelihood bazë }\right)}
$$

Nagelkerke's R2 suggests another type of measurement as follows:

McFadden's 22 is an alternative statistic for measuring the variance of the dependent variable and is calculated:

$$
R_{N}^{2}=\frac{R_{C S}^{2}}{1-e^{\left(\frac{\text { llog-likelihood }_{\text {bazë }}}{n}\right)}} \quad R_{M F}^{2}=1-\frac{\log \text { - likelihood }}{\log \text {-linal }}
$$

\section{Model Summary}

\begin{tabular}{|l|l|l|l|l|}
\hline Step & -2 Log likelihood & $\begin{array}{l}\text { Cox \& Snell R } \\
\text { Square }\end{array}$ & $\begin{array}{l}\text { Nagelkerke } \\
\text { Square }\end{array}$ & R \\
\hline 1 & $35.378 a$ & .685 & & .915 \\
\hline
\end{tabular}

For the regression estimated through SPSS we see that Cox and Snell's R2 is 0.685, while Nagelkerke's R2 is 0.915 . The latest test shows that about $91.5 \%$ of the dependent variable variation is explained by the independent variables in the model. A value above 0.20 or $20 \%$ calculated for $\mathrm{R} 2$ is considered a good measure for explaining the variation of dummy variables. This means that we are satisfied with the level of R2.

Chi-square (Hi-square) statistics ratio with degrees of freedom if this ratio

Turns out to be greater than 1 , and then the over distribution is present in the model. In this case it is $0.345<1$ then it is said that in the evaluated model there is no over distribution. Consequently, the model meets the conditions for assuming the independence of the error term.

The analysis of the logistic model reports that, taking into account all the factors listed, with the exception of the variable the impact of accounting standards all others are important in explaining the differences between accounting and fiscal valuation for entities.

This is true for a level of statistical significance of over $90 \%$ or a tolerance of $0.1(10 \%)$ 33. The model table summarizes and groups the factors according to the level of importance $(90 \%, 95 \%$ and $99 \%)$ that they represent in relation to the dependent variable. 
Of all the hypotheses formulated, only Hypothesis 1 is not accepted or rejected. Others are accepted. Because we have the acceptance of at least one hypothesis, then the third hypothesis is also accepted.

\section{Control of the fourth hypothesis}

The two main tests are the Bartletti sphericity test and the Kaiser-Meyer-Olkin (KMO) sample suitability test. From the analysis of the data in this paper, the KMO and Bartlett test informs that the sample suitability index (KMO) for the whole sample is 0.815 , which we will interpret as the sample is above average in terms of suitability for the type of analysis we are performing. There are eight questions that do not exceed the above limit since these questions do not meet the above condition, then they leave the factor analysis and consequently they are not integrated in the analysis that follows.

Also the variables (questions) are listed from those with higher value loads to those with lower value loads. This is done to facilitate interpretation.

Finally, there are three factors that measure the dimensions of unknown expenditures. They are:

- Debt expenses;

- Expenses for recognition of assets;

- Unjustified expenses with documentation. Finally, there are three factors that measure the dimensions of unknown expenditures.

Component Transformation Matrix

\begin{tabular}{|l|l|l|l|}
\hline Component & 1 & 2 & 3 \\
\hline 1 & .978 & -0.653 & -.023 \\
2 & .051 & .967 & -.294 \\
3 & .048 & .279 & .948 \\
\hline
\end{tabular}

In conclusion, this factorial analysis suggests creating 3 variables instead of some questions related to business costs and expenses. These variables are Debt Expenditures, Asset Recognition Expenditures and Unjustified Documentary Expenditures.

This means that the unrecognized key expenses that affect the calculation and assessment of the entity's profit tax are those expenses that are related to debt expenses, asset recognition expenses and unjustified documentation expenses, which the tax authorities do not recognize them or recognize them in part, despite the fact that they are accounting for real expenses. 


\section{Conclusions and recommendations}

The conclusions generated are in line with the objectives of this study. The following are the main conclusions of the study:

Entities that exercise economic activity are oriented towards the application of the rules of accounting and fiscal standards but dominated by fiscal ones, in assessing their activity and financial condition.

As a result, we can say that these units during the exercise of their activity, tend to be classified in the fifth category, according to the taxonomy of Lamb: in those rating systems in which, in conflict cases where accounting and fiscal rules provide interpretations of different, then the fiscal rules should be resolved (in this case it is said that fiscal reporting dominates, ie tax rules are used in determining tax and accounting profit). This is justified by the argument that such a trend is evident in Eastern European countries, where there is a strong correlation between accounting and fiscal estimates and that financial element were more classified in the fourth and fifth categories. The relationship between accounting and fiscal in Albania is supported by the principle of the link between fiscal and accounting. They are interdependent (hence the relevant reporting). This dependency relationship exists where accounting / financial estimates are based on fiscal rules or fiscal profit is determined by accounting / financial estimates.

The results from the questionnaire show that there are significant differences in accounting and fiscal reporting during the exercise of activity in assessing the activity and financial condition of entities. This can be translated by the fact that these units are "forced" to be part of a reality based on dual reporting models. In other words, entities in the preparation of financial statements pay more attention to the tax result and less to the accounting result; this is the reason for the differences in reporting. The entity attaches more importance to the tax result, because the application and enforcement of fiscal legislation brings tax effects to them, while non-compliance with MRS rules does not bring these tax effects, although this is always at the expense providing complete and reliable accounting information. The relationship between these accounting and fiscal reporting is characterized by a dynamic and a good treatment of this area requires a study extended over a long period of time.

The factors influencing the creation of dual models (based on the results of the analysis) are generally in line with the expectations of the literature reviewed.

The divergences between the accounting and tax methods of valuation in economic units in Albania are influenced, among others, by factors of subjective, decisionmaking, cultural, psychological character, factors related to inheritance, related to mentality, factors that have relate to the professional lifestyle of accounting professionals. 
In fact, the expectations were that national accounting standards would have a significant impact on creating differences in accounting and fiscal reporting. This was not accepted during the analysis of the results despite the fact that the standards themselves have brought many innovations related to valuation, such as great dynamism and progress in accounting valuation, using fair value or market value.

The relationship between the creation of differences and the frequency of changes in fiscal legislation turned out to be significant and is explained by the fact that the more frequent these changes are, the more likely we are to have differences in reporting.

The analysis of the results showed a significant relationship between the creation of differences and different accounting and fiscal goals: the more different the perceptions that the accounting and fiscal goals are different, the greater the chances of having duplicate models reporting. Undoubtedly, tax legislation aims to generate as much revenue as possible.

The results from the factor analysis suggest that the three main components, where the differences in accounting and fiscal reporting are most evident, are debt costs, costs for recognizing assets and those unjustified by documentation. It is these expenses that are recognized according to the accounting rules and are not recognized at all or in part by the tax authorities; as a result they produce differences in estimates, thus not presenting the true and honest picture of the entity.

\section{Recommendation}

The harmonization of accounting and fiscal rules will reduce the duplicate reporting of entities when drafting the FS.

We think that it is important in making changes to get the opinion of professionals in order to improve the "shortcomings" in time in order to increase the quality of reporting such as adding illustrative examples, continuous access to the online package of standards and guidelines.

Consider the possibility of harmonizing and unifying as many accounting and fiscal rules as possible, in such a way as to minimize the gap created between these two reports.

Any changes in fiscal legislation should be made through consultations with stakeholders, especially the business community. The opinion of the business community is very important for building mutual trust.

All actors such as: drafters of FS, tax administration and accountants' associations, should require entities to complete the financial statements according to the improved NAS, because only in this way, the financial statements will give a true picture the reliability of the financial position, financial performance and cash flow of the reporting entity and its reliability to external users. 
Interaction between institutions such as the KKK, the Ministry of Finance should be increased so that laws speak in the same way on specific reporting issues.

\section{References}

[1] Bollano J. Hoxha E. Kontabilitet Financiar, fq.19, Tiranë

[2] Bollano J.(2012) Arritjet, vështirësitë, sfidat e raportimit financiar dhe strategjia e KKK për të ardhmen. Konferenca Kombëtare e KKK në kuadrin e 100 vjetorit të Shpalljes së Pavarësisë , Tiranë. E vlefshme http://kkk.gov.al/artikuj.php?1\&gj=sh

[3] Çela H. (2004). Toëards application of neë standards on accounting and auditing - Albanian challenge, The Fifth Meeting of the South East Europe Corporate Governance Roundtable on implementing IAS/IFRSs and ISAs

[4] Cuzdriorean D. , Deaconu A., 2011. Accounting and the state. On the actual relationship in a post-communist country, paper presented to the 5th AAC Conference, Cluj-Napoca, 21-23 September

[5] Duhanxhiu I. , Kapllani V., (2012), The relationship betëeen financial and tax accounting in Albania, The Romanian Economic Journal, i vlefshëm online : http://www.rejournal.eu/sites/rejournal.versatech.ro/files/articole/201203-01/2038/duhanxhiu.pdf

[6] Gremi E (2014), Disertacion :" Ndikimi i faktorëve specifikë bankarë dhe i atyre makroekonomikë në përfitueshmërinë e bankave shqiptare", Durrës

[7] Hoxha, E; Bollano, J. (2009) "Accounting Standards in Albania: Challenges of first time application of AS in Albania", International Conference "Economic Policy and EU Integration"

[8] Informacioni per legjislacionin tatimor, http://tatime.gov.al

[9] James S. (2009) The Relationship Between Accounting and Taxation, Working paper, fq. 6

[10] James, S. (2009) The Relationship Between Accounting and Taxation, Working Paper Lamb M., Nobes C. W., and Roberts, A. D. (1998) "International Variations in the Connections between Tax and Financial Reporting," Accounting and Business Research, (Summer): 173-188

[11] Miti. M, Dhamo.S (2018) ; "The Impact of Accounting Reforms in Financial Reporting- Case of Albania" European Journal of Economics and Business Studies, Vol 4, Nr.2

[12] Morina M. (2016), “ Raportimi financiar e tatimor i njësive ekonomike shqipëtare", Working paper, Durrës 2016

[13] Nobes C. (2004) "On accounting classification and the international harmonization debate", Accounting, Organizations and Society, vol.34, 189200 
[14] Nobes C. (2006) "The survival of international differences under IFRS: towards a research agenda" Accounting and Business Research, vol. 36,nr. 3: fq. $223-245$

[15] Nobes C. (2006) "The survival of international differences under IFRS: toëards a research agenda" Accounting and Business Research, vol. 36,nr. 3: 223-245

[16] Nobes, C., Schwencke, H.R., 2006. Modelling the links between Tax and Financial Reportings: A Longitudinal Examination of Norway over of 30 years up to IFRS adoption, European Accounting Review,vol. 15, no. 1, q. 63-87

[17] Perri, R; Naqellari J, (2010) "Quality of financial and accounting information in Albania as perceived by the practicing accountants" Discussion paper, University of Tirana, Albania

[18] Plani Kombëtar për Integrimin Evropian 2015 - 2020, www.qbz.gov.al,

[19] Qendra e botimeve zyrtare : www.qbz.gov.al

[20] Shaviro, D. (2009) The Optimal Relationship Between Taxable Income and Financial Accounting Income: Analysis and a Proposal

[21] Shoqata e ekonomistëve europianë : www.fee.be

[22] Standardet Kombëtare të Kontabilitetit të përmirësuara, Botim KKK, Tiranë 2015

[23] Tomja A. (2014) : Implementimi i SKK dhe trajtimi i problemeve të tyre në NVM, Tezë doktorature, Tiranë

[24] Turlea E. \& Nanu M. (2015) ; Dynamics beteeen taxation and accounting at the level of national economic reality, European Journal of Accounting, Finance and Business , fq 10-32 